\title{
Impact of methylene blue and atorvastatin combination therapy on the apparition of cerebral malaria in a murine model
}

\author{
Jérome Dormoi ${ }^{1,2}$, Sébastien Briolant ${ }^{1,2,3,4}$, Camille Desgrouas ${ }^{5}$ and Bruno Pradines ${ }^{1,2^{*}}$
}

\begin{abstract}
Background: Proveblue ${ }^{\circledR}$, a methylene blue dye that complies with European Pharmacopoeia and contains limited organic impurities and heavy metals of recognized toxicity, showed in vitro synergy against Plasmodium falciparum when combined with atorvastatin, an inhibitor of 3-hydroxy-3-methylglutaryl-Coenzyme A reductase. The objective of this study was to evaluate the in vivo efficacy of Proveblue ${ }^{\circledR}$ when combined with atorvastatin in a murine model of experimental cerebral malaria.

Methods: Forty female C57Bl6/N mice were divided into four groups (control, atorvastatin $40 \mathrm{mg} / \mathrm{kg}$ for seven days, Proveblue ${ }^{\circledR} 10 \mathrm{mg} / \mathrm{kg}$ for five days and atorvastatin combined with Proveblue ${ }^{\circledR}$ ), infected with Plasmodium berghei ANKA parasites by intraperitoneal inoculation and observed for 45 days.

Results: Treatment with atorvastatin alone did not demonstrate an effect significantly different from no treatment $(p=0.0573)$. All the mice treated by atorvastatin alone died. Treatment with Proveblue ${ }^{\circledR}$ or a combination of Proveblue $^{\circledR}$ and atorvastatin was significantly increased survival of cerebral malaria ( $p=0.0011$ and 0.0002 , respectively). Although there was only one death in the atorvastatin and Proveblue ${ }^{\circledR}$ combination treatment group $(10 \%)$ versus two deaths (22\%) with Proveblue ${ }^{\circledR}$ treatment, the effect on cerebral malaria was not significant $(p=0.283)$.

Conclusions: The present work demonstrated, for the first time, the high efficacy of Proveblue ${ }^{\circledR}$ in preventing cerebral malaria. Atorvastatin alone or in combination appears to possess limited use for preventing cerebral malaria. Combination of atorvastatin with lower doses of Proveblue ${ }^{\circledR}(<10 \mathrm{mg} / \mathrm{kg} /$ day $)$ should be evaluated to show potential synergistic effects in cerebral malaria prevention.
\end{abstract}

Keywords: Malaria, Plasmodium, Anti-malarial drug, in vivo, Resistance, Methylene blue, Atorvastatin

\section{Background}

In 2002, the World Health Organization (WHO) recommended that artemisinin-based combination therapy (ACT) should be used for all cases of uncomplicated malaria. Four years later, the WHO further recommended that artesunate should be deployed as the first-line treatment for severe malaria in adults and replace quinine due to its efficacy and better tolerance [1]. In 2010,

\footnotetext{
* Correspondence: bruno.pradines@free.fr

'Unité de Parasitologie, Institut de Recherche Biomédicale des Armées, Marseille, France

${ }^{2}$ Unité de Recherche sur les Maladies Infectieuses et Tropicales Emergentes, Aix Marseille Université, UM 63, CNRS 7278, IRD 198, Inserm 1095, Marseille, France

Full list of author information is available at the end of the article
}

a large-scale trial confirmed the potency of artesunate for treating severe malaria in children [2]. In 2011, WHO recommended artesunate as the first-line treatment for severe malaria. Several recent studies have reported clinical failures or extended parasite clearance times in Cambodia [3-5].

There is an urgent need for the discovery of new antimalarial drugs and combination therapy. A combinatorial approach protects each drug from the development of resistance and reduces the overall transmission rate of malaria [6].

Methylene blue $(\mathrm{MB})$ is an old anti-malarial drug that is no longer in use. In 1891, Guttmann and Ehrlich were the first to report the anti-malarial properties of a

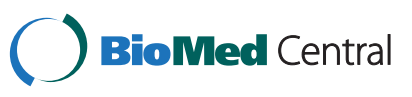


synthetic thiazine dye, methylene blue, when they described the clinical cure of two patients after oral administration of $\mathrm{MB}$ [7]. Cardamatis wrote in Progrès Médical that he had found MB to be very effective in the early stages of severe malaria cachexia in cases that were resistant to quinine [8]. MB has shown in vitro activity against Plasmodium falciparum strains $[9,10]$ or isolates [11,12] and in vivo activity against Plasmodium vinckei and Plasmodium yoelii parasites [13,14].

Currently, there is no $\mathrm{MB}$ available globally that complies with European Pharmacopoeia. To date, the pharmaceutical use of MB has been stymied by contamination with organic impurities and heavy metals with recognized toxicity. Provence Technologies and its subsidiary, Provepharm, have conducted four years of research that resulted in the first European Pharmacopoeia-grade MB: Proveblue ${ }^{\circledR}$. This drug was obtained from an innovative synthetic and heavy-metal-free pathway using pharmaceutical-grade reagents (patent application $\mathrm{N}^{\circ} \mathrm{FR} 06 /$ 06330, which has been extended to the international PCT reference PCT/FR/2007/001193). The total concentration of metals, Azure B (the most important impurity in $\mathrm{MB}$ ) and other impurities in Proveblue ${ }^{\circledR}$ is $<20 \mathrm{ppm},<2 \%$, $<0.5 \%$, respectively. Proveblue ${ }^{\circledR}$ has in vitro anti-malarial activity (mean $\mathrm{IC}_{50}=3.62 \mathrm{nM}$ ) against $23 P$. falciparum strains that are resistant to other anti-malarial drugs [15]. No significant association was found between the Proveblue $\mathrm{IC}_{50}$ and polymorphisms in the genes that are involved in quinoline resistance, such as pfcrt, pfmdr1, $p f m d r 2$, pfmrp and pfnhe-1; furthermore, there is no significant association between the Proveblue $\mathrm{IC}_{50}$ and the copy numbers of pfmdr1 and pfmdr2 [15]. While Proveblue ${ }^{\circledR}$ has in vitro antagonistic effects when combined with chloroquine and additive effects when combined with desethylamodiaquine against nine $P$. falciparum strains, Proveblue ${ }^{\circledR}$ exhibited noticeable synergistic effects when combined with mefloquine and quinine and high synergistic effects when combined with dihydroartemisinin, the active metabolite of artemisinin derivatives [16].

Statins, the inhibitors of 3-hydroxy-3-methylglutarylCoenzyme A reductase (HMG-CoA reductase) and a family of lipid-lowering drugs, have in vitro anti-malarial properties [17,18]. Atorvastatin (AVA), like the other statins, is not a highly active blood schizonticidal antimalarial drug with $\mathrm{IC}_{50}$ values ranged from 2.5 to $12 \mu \mathrm{M}$ $[17,18]$. Its application in malaria chemotherapy would be for adjuvant treatment. Moreover, AVA improved the in vitro activity of mefloquine [19], quinine [20], dihydroartemisinin [21] and Proveblue ${ }^{\circledR}$ [16] at the plasma concentrations expected in clinical observations in patients taking $80 \mathrm{mg}$ of AVA daily $(0.1$ to $0.5 \mu \mathrm{M})$ [22]. However, AVA used alone failed to prevent death from cerebral malaria or to affect the parasitaemia of infected mice [23]. AVA combined with mefloquine led to a significant delay in mouse death and had an effect on the onset of cerebral malaria symptoms [24].

The objective of the present work was to evaluate the in vivo efficacy of Proveblue ${ }^{\circledR}$ when combined with AVA in a murine model of experimental cerebral malaria. While animal models do not exactly reproduce human malaria, they nevertheless exhibit some similarities to human cerebral malaria, and the Plasmodium berghei ANKA rodent parasite model is generally accepted as valid for studying experimental cerebral malaria pathogenesis $[25,26]$.

\section{Methods}

\section{Mice and experimental cerebral malaria}

Forty female $\mathrm{C} 57 \mathrm{Bl6} / \mathrm{N}$ mice, six to seven weeks old and weighing 18-22 g (Charles Rivers, France), were infected on day 0 (D0) with P. berghei ANKA parasites by intraperitoneal (ip) inoculation. The inoculum contained $10^{5}$ parasitized erythrocytes extracted from infected donor C57B16/N mice and diluted in $200 \mu \mathrm{l}$ normal saline. All animals were pathogen-free and were housed under standard conditions, with unlimited access to food and water. All efforts were made to minimize animal suffering. All experiments adhered to French guidelines for animal research and were approved by the ethical committee of the Institut de Recherche Biomédicale des Armées - Antenne de Marseille (Number 2007-09).

Except for the control group (8 mice), mice were treated daily when parasitaemia reached $0.1 \%$ by ip injection with $40 \mathrm{mg} / \mathrm{kg}$ AVA for seven days (7 mice), $10 \mathrm{mg} / \mathrm{kg}$ Proveblue $^{\circledR}$ for five days (9 mice) or $40 \mathrm{mg}$ AVA for seven days combined with $10 \mathrm{mg} / \mathrm{kg}$ Proveblue ${ }^{\circledR}$ during five days (10 mice). AVA calcium salt was dissolved in $1 \%$ dimethyl sulfoxyde (vol/vol) in $0.9 \% \mathrm{NaCl}$. The solution of $1 \%$ dimethyl sulfoxyde ( $\mathrm{vol} / \mathrm{vol}$ ) in $0.9 \% \mathrm{NaCl}$ was ip administered to control mice (after previously evaluation of absence of effect in infected and non-infected mice in comparison with $0.9 \% \mathrm{NaCl}$ ). Proveblue ${ }^{\circledR}$ was dissolved in $0.9 \% \mathrm{NaCl}$.

Parasitaemia was determined daily using Giemsastained thin blood smears collected from the tail vein. Parasitaemia was calculated by the number of infected red blood cells per 3,000 erythrocytes if $>1 \%$ cells were infected and per 10,000 erythrocytes if $<1 \%$ cells were infected. The animals were under daily supervision for clinical signs, neurological symptoms and weight. Experimental cerebral malaria was diagnosed by clinical signs based on a simplified SHIRPA protocol [27] with at least two symptoms in at least two of the three different groups: 1) alteration of autonomous function (piloerection, defecation, urination, respiration rate); 2) alteration of muscle tone and strength (grip strength, body 
tone, limb tone, abdominal tone); and, 3) ataxia, paralysis (mono-, hemi-, para-, or tetraplegia), deviation of the head, convulsions and coma.

\section{Statistical analysis}

The data were analysed using $\mathrm{R}$ software ${ }^{\circledR}$ (version 2.10.1). Survival analyses were performed by the KaplanMeier log rank test. The comparison of medians between multiple groups was analysed by the Kruskal-Wallis test. The comparison of medians between two groups was analysed by the Mann-Whitney test. A difference was considered significant when P-values were less than 0.05 .

\section{Results}

In the control group, all the mice died before D10, with specific signs of cerebral malaria and parasitaemia $<10.5 \%$ (6.7-10.5\%) (Figure 1). The mice treated with $40 \mathrm{mg} / \mathrm{kg}$ AVA died between D5 and D9 (29\% of the experimental group) with specific cerebral malaria symptoms and parasitaemia (5.7-6.8\%) or between D18 and D24 with anaemia and parasitaemia (94.2-98.4\%). In the group of mice treated with $10 \mathrm{mg} / \mathrm{kg}$ Proveblue ${ }^{\circledR}$, one mouse $(11 \%)$ had recurrent parasites at D5 and died at D16 (50.0\% parasitaemia), and another had recurrent parasites at D11 and died at D25 (91.7\% parasitaemia). These two mice died with no specific signs of cerebral malaria. After two days of treatment with Proveblue ${ }^{\circledR}$, no parasite was detectable by blood smear. At D45, the surviving mice had no parasites. In the group of mice treated with $40 \mathrm{mg} / \mathrm{kg}$ AVA combined with $10 \mathrm{mg} / \mathrm{kg}$ Proveblue ${ }^{\circledR}$, one mouse $(10 \%)$ had recurrent parasites at D10 and died at D14 (6.6\% parasitaemia) with specific signs of cerebral malaria. At D45, the surviving mice had no parasites.

\section{Discussion}

Treatment with AVA alone did not demonstrate an effect significantly different from no treatment $(p=0.0573)$. All the mice treated by AVA alone died. These results confirm that in an experimental cerebral malaria model, therapeutic ip AVA treatment, similar to other statins, shows no effect on the incidence of cerebral malaria [23,24,28,29]. The pathogenesis of cerebral malaria in the murine model relies solely on the inflammatory response, unlike the pathogenesis of human cerebral malaria. Indeed, the cytoadherence phenomenon does not exist in $P$. berghei mice infections [30,31]. AVA strongly protects endothelial cell against $P$. falciparum-induced collateral damages, cell apoptosis and endothelial barrier permeabilization [32]. AVA can be used to reduce $P$. falciparum cytoadherence to endothelial cells; cytoadherence and the inflammatory burst are the key events of pathogenesis in severe human malaria. In mice with $P$. berghei ANKA cerebral malaria, lovastatin reduces pro-inflammatory cytokines in the brain and prevents cognitive impairment [33].

Treatment with Proveblue ${ }^{\circledR}$, or a combination of Proveblue $^{\circledR}$ and AVA, significantly reduced or prevented cerebral malaria $(\mathrm{p}=0.0011$ and 0.0002 , respectively). A Proveblue ${ }^{\circledR}$ regimen of $10 \mathrm{mg} / \mathrm{kg}$ resulted in a $75 \%$ survival rate. This dosage is safe in children treated with methylene blue that was non-compliant with the European Pharmacopoeia [34,35]. Methylene blue at doses ranged from $12 \mathrm{mg} / \mathrm{kg} /$ day to $24 \mathrm{mg} / \mathrm{kg} /$ day for three days were administered to children with uncomplicated malaria in Burkina-Faso. Only one mouse died in the AVA and Proveblue ${ }^{\circledR}$ combination treatment group. The combination of Proveblue ${ }^{\circledR}$ and AVA was more effective than AVA alone in the experimental cerebral malaria mouse model $(p=0.0012)$. Although there was only one death with AVA plus Proveblue ${ }^{\circledR}$ treatment $(10 \%)$ versus two deaths (22\%) with Proveblue ${ }^{\circledR}$ alone, the effect on cerebral malaria was not significant $(p=0.283)$. Thus, the efficacy of the combination may be due to the effect of Proveblue $^{\circledR}$, not as a result of a synergism between the two compounds. The dose of $10 \mathrm{mg} / \mathrm{kg}$ of Proveblue ${ }^{\circledR}$ for

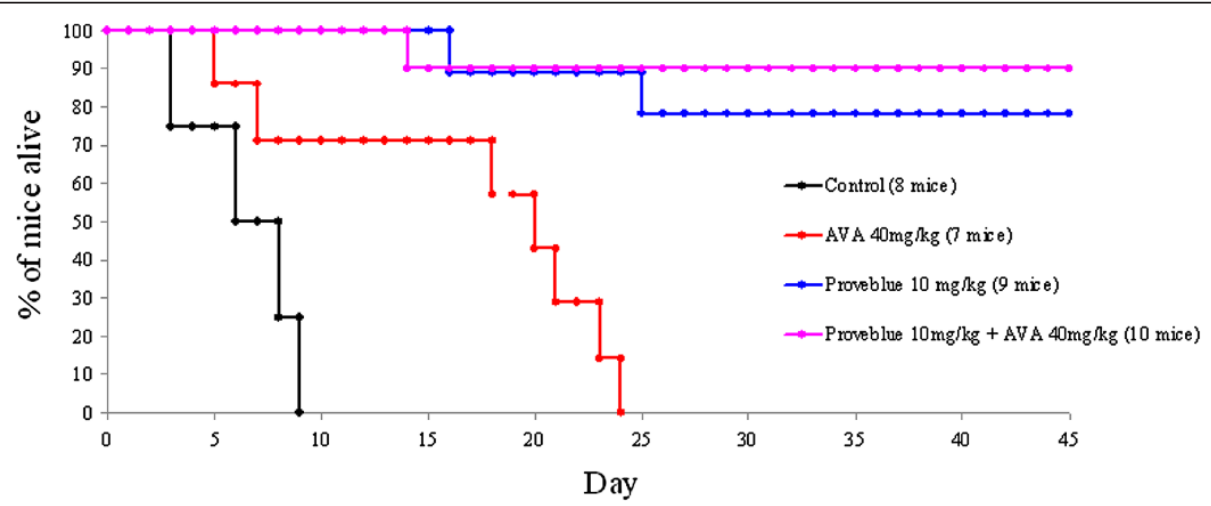

Figure 1 Survival curve of C57BI6/N mice infected on day 0 (D0) with Plasmodium berghei ANKA parasites and treated with $40 \mathrm{mg} / \mathrm{kg}$ atorvastatin (AVA) for seven days, $10 \mathrm{mg} / \mathrm{kg}$ Proveblue ${ }^{\circledR}$ for five days or $40 \mathrm{mg}$ atorvastatin for seven days combined with $10 \mathrm{mg} / \mathrm{kg}$ Proveblue ${ }^{\circledR}$ for five days. 
five days, which showed a high efficacy when used alone, seems to be too high to show synergistic effects in combination with AVA. Combination with lower doses of Proveblue ${ }^{\circledR}$ should be evaluated. Proveblue ${ }^{\circledR}$ or AVA plus Proveblue ${ }^{\circledR}$ treatments are more effective than AVA and mefloquine combinations, which can delay mouse death and/or the onset of cerebral malaria but do not prevent death by anaemia [24]. The role of AVA in inhibiting cytoadherence in humans is not evaluable in mice, as this phenomenon does not exist in the P. berghei murine malaria model.

For the first time, the present work demonstrated the high efficacy of Proveblue ${ }^{\circledR}$ in preventing cerebral malaria. Another advantage of Proveblue ${ }^{\circledR}$ as an antimalarial drug is that $\mathrm{MB}$ inhibits the maturation and transmission of gametocytes [36-38]. Of 44 compounds provided by Medicines for Malaria Venture, MB was the most active compound and reduced gametocyte viability with an $\mathrm{IC}_{50}$ value of $12 \mathrm{nM}$ [39]. These results confirm the therapeutic potential of Proveblue ${ }^{\circledR}$, a new MB formulation with limited organic impurities and toxic heavy metals that could be integrated into the pipeline of antimalarial combination therapy [40]. AVA alone appears to possess limited use for preventing cerebral malaria. However, Proveblue ${ }^{\circledR}$ and AVA have different and complementary properties (effects on asexual stages, gametocyte maturation and transmission, cytoadherence, and pro-inflammatory cytokine levels), which makes them interesting partners for future investigation using combination therapy. Combination of AVA with lower doses of Proveblue ${ }^{\circledR}$ should be evaluated to show potential synergistic effects in cerebral malaria prevention. The present work demonstrated the high efficacy of Proveblue ${ }^{\circledR}$ in preventing cerebral malaria. The efficacy of Proveblue ${ }^{\circledR}$ and combination of AVA and Proveblue ${ }^{\circledR}$ should be evaluated in treating murine cerebral malaria.

\section{Competing interests}

All authors declare that they have no potential conflicts of interest.

\section{Authors' contributions}

JD and CD carried out the in vivo study. SB and BP conceived and coordinated the study. JD and SB analysed the data. JD and BP drafted the manuscript. All the authors read and approved the final manuscript.

\section{Funding}

This study was supported by the Délégation Générale pour l'Armement (grant no PDH-2-NRBC-4-B1-402)

\section{Author details}

${ }^{1}$ Unité de Parasitologie, Institut de Recherche Biomédicale des Armées, Marseille, France. ${ }^{2}$ Unité de Recherche sur les Maladies Infectieuses et Tropicales Emergentes, Aix Marseille Université, UM 63, CNRS 7278, IRD 198, Inserm 1095, Marseille, France. ${ }^{3}$ Direction Interarmées du Service de Santé, Cayenne, Guyane. ${ }^{4}$ Laboratoire de Parasitologie, Institut Pasteur de la Guyane, Cayenne, Guyane. ${ }^{5}$ UMR MD3, Aix Marseille Université, Institut de Recherche Biomédicale des Armées, Marseille, France.

Received: 1 March 2013 Accepted: 10 April 2013

Published: 15 April 2013

\section{References}

1. Dondorp A, Nosten F, Stepniewska K, Day N, White N, South-East Asian Quinine Artesunate Malaria Trial (SEAQUAMAT) group: Artesunate versus quinine for treatment of severe falciparum malaria: a randomised trial. Lancet 2005, 366:717-735.

2. Dondorp AM, Fanello Cl, Hendriksen ICE, Gomes E, Seni A, Chhaganlal KD, Bojang K, Olaosebikan R, Anunobi N, Maitland K, Kivaya E, Agbenyega T, Blay Nguah S, Evans J, Gesase S, Kahabuka C, Mtove G, Nadjm B, Deen J, Mwanga-Amumpaire J, Nansumba M, Karema C, Umulisa N, Uwimana A, Mokuolu OA, Adedoyin OT, Jonhson WBR, Tshefu AK, Onyamboko MA, Sakulthaew T, et al: Artesunate versus quinine in the treatment of severe falciparum malaria in African children (AQUAMAT): an open-label, randomised trial. Lancet 2010, 376:1647-1657.

3. Noedl H, Se Y, Schaecher K, Smith BL, Socheat D, Fukuda MM: Evidence of artemisinin-resistant malaria in western Cambodia. N Engl J Med 2008, 359:2619-2620.

4. Dondorp AM, Nosten F, Yi P, Das D, Phyo AP, Tarning J, Lwin KM, Ariey F, Hanpithakpong W, Lee SJ, Ringwald P, Silamut K, Imwrong M, Chotivanish K, Lim P, Herdman T, An SS, Yeung S, Singhasivanon P, Day NPJ, Lindegardh $\mathrm{N}$, Socheat D, White NJ: Artemisinin resistance in Plasmodium falciparum malaria. N Engl J Med 2009, 361:455-467.

5. Amaratunga C, Sreng S, Suon S, Phelps ES, Stepniewska K, Lim P, Zhou C, Mao S, Anderson JM, Lindegardh N, Jiang H, Song J, Su XZ, White NJ, Dondorp AM, Anderson TCJ, Fay MP, Mu J, Duong S, Fairhurst RM: Artemisinin-resistant Plasmodium falciparum in Pursat province, western Cambodia: a parasite clearance rate study. Lancet Infect Dis 2012, 12:851-858.

6. White NJ: Preventing antimalarial drug resistance through combinations. Drug Resist Updat 2001, 1:3-9.

7. Guttmann P, Ehrlich P: Ueber die wirkung des methylenblau bei malaria. Berlin Klin Wochenschr 1891, 28:953-956.

8. Anonymous: Methylene blue in grave malaria cachexia. J Am Med Assoc 1900, 34:1409.

9. Akoachere M, Buchholz K, Fischer E, Burhenne J, Haefeli WE, Schirmer RH, Becker $\mathrm{K}$ : In vitro assessment of methylene blue on chloroquine-sensitive and -resistant Plasmodium falciparum strains reveals synergistic action with artemisinins. Antimicrob Agents Chemother 2005, 49:4592-4597.

10. Garavito G, Bertani S, Rincon J, Maurel S, Monje MC, Landau I, Valentin A Deharo E: Blood schizontocidal activity of methylene blue in combination with antimalarials against Plasmodium falciparum. Parasite 2007, 14:135-140.

11. Ademowo OG, Nneji CM, Adedapo ADA: In vitro antimalarial activity of methylene blue against field isolates of Plasmodium falciparum from children in Southwest Nigeria. Indian J Med Res 2007, 126:45-49.

12. Okombo J, Kiara SM, Mwai L, Pole L, Ohuma E, Ochola LI, Nzila A: Baseline in vitro activities of the antimalarials pyronaridine and methylene blue against Plasmodium falciparum isolates from Kenya. Antimicrob Agents Chemother 2012, 56:1105-1107.

13. Atamna H, Krugliak M, Shalmiev G, Deharo E, Pescarmona G, Ginsburg H: Mode of antimalarial effect of methylene blue and some of its analogues on Plasmodium falciparum in culture and their inhibition of P. vinckei petteri and P. yoelii nigeriensis in vivo. Biochem Pharmacol 1996, 51:693-700

14. Garavito G, Bertani S, Quiliano M, Valentin A, Aldana I, Deharo E: The in vivo antimalarial activity of methylene blue combined with pyrimethamine, chloroquine and quinine. Mem Inst Oswaldo Cruz 2012, 107:820-823.

15. Pascual A, Henry M, Briolant S, Charras S, Baret E, Amalvict R, Huyghues des Etages E, Feraud M, Rogier C, Pradines B: In vitro activity of Proveblue (Methylene Blue) on Plasmodium falciparum strains resistant to standard antimalarial drugs. Antimicrob Agents Chemother 2011, $55: 2472-2474$

16. Dormoi J, Pascual A, Briolant S, Amalvict R, Charras S, Baret E, Huyghues des Etages E, Feraud M, Pradines B: Proveblue (Methylene Blue) as antimalarial agent: In vitro synergy with dihydroartemisinin and atorvastatin. Antimicrob Agents Chemother 2012, 56:3467-3469.

17. Pradines B, Torrentino-Madamet M, Fontaine A, Henry M, Baret E, Mosnier J, Briolant S, Fusai T, Rogier C: Atorvastatin is 10 -fold more active in vitro than other statins against Plasmodium falciparum. Antimicrob Agents Chemother 2007, 51:2654-2655.

18. Parquet $V$, Briolant $S$, Torrentino-Madamet M, Henry M, Almeras L, Amalvict $R$, Baret E, Fusai T, Rogier C, Pradines B: Atorvastatin is a promising partner for 
antimalarial drugs in treatment of Plasmodium falciparum malaria. Antimicrob Agents Chemother 2009, 53:2248-2252.

19. Wurtz N, Briolant S, Gil M, Parquet V, Henry M, Baret E, Amalvict R, Almeras L, Rogier C, Pradines B: Synergy of mefloquine activity with atorvastatin, but not chloroquine and monodesethylamodiaquine, and association with the pfmdr1 gene. J Antimicrob Chemother 2010, 65:1387-1394.

20. Parquet V, Henry M, Wurtz N, Dormoi J, Briolant S, Gil M, Baret E, Amalvict R, Rogier C, Pradines B: Atorvastatin as a potential anti-malarial drug: in vitro synergy in combinational therapy with quinine against Plasmodium falciparum. Malar J 2010, 9:139.

21. Savini H, Souraud JB, Briolant $S$, Baret E, Amalvict R, Rogier C, Pradines B: Atorvastatin as a potential antimalarial drug: in vitro synergy in combinational therapy with dihydroartemisinin. Antimicrob Agents Chemother 2010, 54:966-967.

22. Borek-Dohalsky V, Huclova J, Barrett B, Nemec B, Ulc I, Jelinek I: Validated HPLC-MS-MS method for simultaneous determination of atorvastatin and 2-hydroxyatorvastatin in human plasma-pharmacokinetic study. Anal Bioanal Chem 2006, 386:275-285.

23. Bienvenu AL, Picot S: Statins alone are ineffective in cerebral malaria but potentiate artesunate. Antimicrob Agents Chemother 2008, 52:4203-4204.

24. Souraud JB, Briolant S, Dormoi J, Mosnier J, Savini H, Baret E, Amalvict R, Soulard R, Rogier C, Pradines B: Atorvastatin treatment is effective when used in combination with mefloquine in an experimental cerebral malaria murine model. Malar J 2012, 11:13.

25. Lou J, Lucas R, Grau GE: Pathogenesis of cerebral malaria: recent experimental data and possible applications for humans. Clin Microbiol Rev 2001, 14:810-820.

26. Delahaye NF, Coltel N, Puthier D, Barbier M, Benech P, Joly F, Iraqi FA, Grau GE, Nguyen C, Rihet P: Gene expression analysis reveals early changes in several molecular pathways in cerebral malaria-susceptible mice versus cerebral malaria-resistant mice. BMC Genomics 2007, 8:452.

27. Lackner P, Beer R, Heussler V, Goebel G, Rudzki D, Helbok R, Tannich E, Schmutzhard E: Behavioural and histopathological alterations in mice with cerebral malaria. Neuropathol Appl Neurobiol 2006, 32:177-188.

28. Helmers AJ, Gowda DC, Kain KC, Liles WC: Statins fail to improve outcome in experimental cerebral malaria and potentiate Toll-like receptor-mediated cytokine production by murine macrophages. Am J Trop Med Hyg 2009, 81:631-637.

29. Kobbe R, Schreiber N, May J, Jacobs T: Simvastatin treatment shows no effect on the incidence of cerebral malaria or parasitemia during experimental malaria. Antimicrob Agents Chemother 2008, 52:1583-1584

30. Lackner P, Beer R, Helbok R, Broessner G, Engelhardt K, Brenneis C, Schmutzhard E, Pfaller K: Scanning electron microscopy of the neuropathology of murine cerebral malaria. Malar J 2006, 5:116.

31. White NJ, Turner GD, Medana IM, Dondorp AM, Day NP: The murine cerebral malaria phenomenon. Trends Parasitol 2010, 26:11-15.

32. Taoufiq Z, Pino P, N'Dilimabaka N, Arrouss I, Assi S, Soubrier F, Rebollo A Mazier D: Atorvastatin prevents Plasmodium falciparum cytoadherence and endothelial damage. Malar J 2011, 10:52.

33. Reis PA, Estato V, da Silva TI, D'Avila JC, Siqueira LD, Assis EF, Bozza PT, Bozza FA, Tibiriça EV, Zimmerman GA, Castro-Faria-Neto HC: Statins Decrease Neuroinflammation and Prevent Cognitive Impairment after Cerebral Malaria. PLoS Pathog 2012, 8:1003099.

34. Coulibaly B, Zoungrana A, Mockenhaupt FP, Schirmer RH, Klose C, Mansmann U, Meissner $P$, Müller $O$ : Strong gametocytocidal effect of methylene blue-based combination therapy against falciparum malaria: A randomized controlled trial. Plos One 2009, 4:5318.

35. Meissner PE, Mandi G, Coulibaly B, Witte S, Tapsoba T, Mansmann U, Rengelshausen J, Schiek W, Jahn A, Walter-Sack I, Mikus G, Burhenne J, Riedel KD, Schirmer RH, Kouyaté B, Müller O: Methylene blue for malaria in Africa: results from a dose-finding study in combination with chloroquine. Malar J 2006, 5:84.

36. Adjalley SH, Johnston GL, Li T, Eastman RT, Ekland EH, Eappen AG, Richman A, Sim BK, Lee MC, Hoffman SL, Fidock DA: Quantitative assessment of Plasmodium falciparum sexual development reveals potent transmission-blocking activity by methylene blue. Proc Natl Acad Sci USA 2011, 108:1214-1223.

37. Lelièvre J, Almeda MJ, Lozano S, Miguel C, Franco V, Leroy D, Herreros E: Activity of clinical relevant antimalarial drugs on Plasmodium falciparum mature gametocytes in an ATP bioluminescence transmission blocking assay. PLoS One 2012, 7:35019.
38. Kasozi DM, Gromer S, Adler H, Zocher K, Rahlfs S, Wittlin S, Fritz-Wolf K Schirmer RH, Becker K: The bacterial redox signaller pyocyanin as an antiplasmodial agent: comparisons with its thioanalog methylene blue. Redox Rep 2011, 16:154-165.

39. Peatey $C L$, Leroy D, Gardiner DL, Trenholme KR: Anti-malarial drugs: how effective are they against Plasmodium falciparum gametocytes? Malar $\rfloor$ 2012, 11:34.

40. Anthony MP, Burrows JN, Duparc S, Moehrle J, Wells TNC: The global pipeline of new medicines for the control and elimination of malaria. Malar J 2012, 11:316.

doi:10.1186/1475-2875-12-127

Cite this article as: Dormoi et al:: Impact of methylene blue and atorvastatin combination therapy on the apparition of cerebral malaria in a murine model. Malaria Journal 2013 12:127.

\section{Submit your next manuscript to BioMed Central and take full advantage of:}

- Convenient online submission

- Thorough peer review

- No space constraints or color figure charges

- Immediate publication on acceptance

- Inclusion in PubMed, CAS, Scopus and Google Scholar

- Research which is freely available for redistribution

Submit your manuscript at www.biomedcentral.com/submit
C Biomed Central 